\title{
David Thomas, Barbara Roggema (eds.). Christian- Muslim Relations: a Bibliographical History
}

\section{Denise Aigle}

\section{(2) OpenEdition}

1 Journals

\section{Édition électronique}

URL : http://journals.openedition.org/abstractairanica/40154

DOI : 10.4000/abstractairanica.40154

ISSN : 1961-960X

Éditeur:

CNRS (UMR 7528 Mondes iraniens et indiens), Éditions de l'IFRI

\section{Édition imprimée}

Date de publication : 1 décembre 2013

ISSN : 0240-8910

\section{Référence électronique}

Denise Aigle, «David Thomas, Barbara Roggema (eds.). Christian-Muslim Relations: a Bibliographical History », Abstracta Iranica [En ligne], Volume 32-33 | 2013, document 217, mis en ligne le 01 juillet 2016, consulté le 26 septembre 2020. URL : http://journals.openedition.org/abstractairanica/40154 ; DOI : https://doi.org/10.4000/abstractairanica.40154

Ce document a été généré automatiquement le 26 septembre 2020.

Tous droits réservés 


\title{
David Thomas, Barbara Roggema (eds.). Christian-Muslim Relations: a Bibliographical History
}

\author{
Denise Aigle
}

\section{RÉFÉRENCE}

David Thomas, Barbara Roggema (eds.). Christian-Muslim Relations: a Bibliographical History. Vol. 1 (600-900). Leyde \& Boston, Brill, 2009, 957 p., index.

1 Cet ouvrage est le premier d'une histoire générale des relations entre chrétiens et musulman (CMR 1), telles quelles ressortissent des sources textuelles. Ce premier volume couvre les années 600-900, le deuxième, les années 900-1200 et le troisième, les années, 1200-1500. Ils sont tous organisés de manière identique. Le CMR 1 débute par des études thématiques qui présentent les données par grands types de sources: Christians and Christianity » dans le Coran (p. 21-30), l'exégèse islamique (p. 31-56), la Sira de Muhammad (p. 57-71), dans les ouvrages de hadiths avant 900 (p.73-82); «Muslims in canon law, 650-1000» (p. 83-98); «Christians in the early and classical Sunnī law » (p. 99-114). Le cœur de l'ouvrage (p. 117-922) consiste en une présentation commentée de chaque œuvre textuelle qui apporte des informations sur les relations entre ces communautés. Toutes les « fiches » sont présentées selon le même modèle. Un index des noms (p. 923-957) et des titres d'ouvrages (p. 944-957) complètent l'ouvrage. Il constitue aujourd'hui un manuel bibliographique de référence incontournable. 


\section{AUTEURS}

DENISE AIGLE

EPHE, Paris 